\title{
A Plum Marbling Conundrum: Identification of a New Viroid Associated with Marbling and Corky Flesh in Japanese Plums
}

\author{
Rachelle Bester, ${ }^{1,2}$ Sophia S. Malan, ${ }^{3}$ and Hans J Maree ${ }^{1,2, \dagger}$ \\ ${ }^{1}$ Department of Genetics, Stellenbosch University, Private Bag X1, Matieland, 7602, South Africa \\ ${ }^{2}$ Citrus Research International, P.O. Box 2201, Matieland, 7602, South Africa \\ ${ }^{3}$ SAPO Trust, Private Bag X5023, Stellenbosch, 7599, South Africa \\ Accepted for publication 6 April 2020.
}

\begin{abstract}
Over the past 2 decades, fruit symptoms resembling a marbling pattern on the fruit skin or corking of the fruit flesh were observed on Japanese plums in South Africa, resulting in unmarketable fruit. The ability of high-throughput sequencing (HTS) to detect known and unknown pathogens was exploited by assaying affected and unaffected fruit tree accessions to identify the potential aetiological agent of marbling and/or corky flesh disease. In this study, it is shown that the disease is associated with a previously undescribed small RNA with typical viroid structural features. The potential viroid was the only pathological agent consistently detected in all symptomatic trees by HTS, and the association with the symptoms was confirmed in field surveys over two seasons. To date, this RNA was not detectable by RTPCR in seedlings raised from seeds collected from infected trees.
\end{abstract}

ABSTRACT
Although the autonomous replication of this viroid-like RNA was not proven, it was shown to be transmissible by grafting and associated with a range of symptoms that include marbling on the fruit skin, corky flesh, reduced fruit size, irregular shape, and uneven fruit surface depending on the cultivar. Moreover, the circular RNA genome, consisting of 317 nucleotides, strongly supports that this viroid-like RNA is most likely a viroid for which the name plum viroid I (PVd-I) is proposed. The primary structure of this viroid showed a less than 90\% nucleotide sequence identity to viroids of the genus Apscaviroid, with which it has close phylogenetic relationships and shares conserved structural motifs.

Keywords: apscaviroid, plum viroid I, Pospiviroidae
Japanese plums (Prunus salicina) are an economically important stone fruit in South Africa produced primarily for the fresh fruit export market. Both abiotic and biotic stress influence the sustainability and profitability of the plum industry that is already under strain from drought with the 2017/2018 season producing $17 \%$ less export fruit compared with the 2016/2017 season (Hortgro 2018). Plums are susceptible to various pathogens including viroids that can cause diseases. Viroids are small circular single-stranded RNAs of less than 400 nucleotides (nts) that can replicate autonomously and do not code for any proteins (Diener 1999; Di Serio et al. 2014; Flores et al. 1997). Taxonomically, viroids are divided into the families Pospiviroidae and Avsunviroidae. Only two viroid species are known to infect cultivated, deciduous stone fruits, namely peach latent mosaic viroid (PLMVd) and hop stunt viroid (HSVd).

For the last 20 years, the South African plum industry observed disease symptoms on various plum cultivars that could not be consistently associated with any aetiological agent. The symptom description overlaps with what was known for plum pseudopox that is associated with apple chlorotic leaf spot virus (ACLSV) (Myrta et al. 2011). However, not all symptomatic plum trees tested positive for ACLSV by either enzyme-linked immunosorbent assay (ELISA) or RT-PCR. Symptom severity also varied from year to year and anecdotal evidence suggested that the disease could be linked to abiotic stress. Due to the severe influence on the fruit, either corky flesh that resulted in dried inedible fruit or skin

†Corresponding author: H. J. Maree; hjmaree@sun.ac.za

Funding: Support was provided by Hortgro (Project GenUS18-Stone).

The author(s) declare no conflict of interest.

(C) 2020 The American Phytopathological Society marbling that changed the cultivar characteristics, the disease was managed by not harvesting the symptomatic fruit and subsequently removing the trees from the orchard.

Fruit tree certification schemes ensure that new plant material is free of known economically important viruses and viroids but require a combination of molecular, serological, and biological assays to detect these pathogens. However, novel viruses and viroids can remain undetected. With high-throughput sequencing (HTS) gaining momentum in the field of virus detection and discovery (Jakse et al. 2015; Maree et al. 2018; Massart et al. 2014; Navarro et al. 2017, 2018; Rott et al. 2017, 2018; Sõmera et al. 2019; Villamor et al. 2016), it provides the ideal opportunity to use this technology for the detection of multiple viruses and viroids in a single assay but also for the identification of novel pathogens for which a detection assay is not yet available.

To investigate the marbling and corky flesh disease with unknown etiology, HTS was applied to both symptomatic and healthy plum trees. A novel viroid-like RNA was identified in only the symptomatic trees and surveys were performed to confirm its association with observed symptoms. Molecular characterization of the viroid-like RNA indicates that it is likely a novel viroid with molecular signatures of and phylogenetic relationships with other viroids classified in the genus Apscaviroid (family Pospiviroidae). Therefore, the name plum viroid I (PVd-I) is proposed to designate it.

\section{MATERIALS AND METHODS}

Field-collected tree samples for HTS and RT-PCR assays. Ten symptomatic (either skin marbling or corky flesh) and five healthy trees previously evaluated for symptoms and reported to be negative for ACLSV with both ELISA and RT-PCR were selected for HTS analysis. These 15 plants represented four plum cultivars (Ruby Crunch, Ruby Star, African Delight, and 
Laetitia) collected from four different orchards in the Western Cape, South Africa. Leaves were collected from these 15 plants early in the 2017/2018 season for HTS analysis. Later in the 2017/2018 season, after fruit coloration was complete and symptoms were visible, these 15 plants were sampled again together with an additional 15 healthy and 20 symptomatic samples representing an extra three locations in the Western Cape, South Africa. In the 2018/ 2019 season, the survey was expanded and 191 leaf samples were collected of which 94 were from trees with symptomatic fruit and 97 were from trees with healthy fruit. Samples were collected from nine different cultivars (African Delight, Black Pearl, Lady Red, Laetitia, Pioneer, Ruby Crunch, Ruby Star, Ruby Sun, and Sun Breeze) in 34 different orchards on 17 farms in the Western Cape, South Africa.

RNA extractions. Total RNA was extracted from $1 \mathrm{~g}$ of leaf material using a modified CTAB extraction protocol (Ruiz-García et al. 2019). Leaf material from all samples included the leaf petiole and $1 \mathrm{~cm}$ of the leaf lamina and midrib at the base of the leaf. Integrity and purity of the RNA was assessed using agarose gel electrophoresis, spectrophotometry (NanoDrop 2000, Thermo Scientific), and the Agilent Bioanalyzer for samples sent for HTS analyses. Total RNA extracts were used for preparation of HTS libraries, RT-PCR amplification, and Sanger sequencing.

HTS and data analysis. Ribo-depleted RNA libraries were constructed with the Illumina TruSeq Stranded Total RNA Sample Preparation kit with Plant Ribo-Zero at Macrogen (South Korea). Paired-end HTS $(2 \times 100$ bp $)$ was performed on an Illumina NextSeq instrument (Macrogen, South Korea). Adapter sequences were removed and data trimmed for quality using Trimmomatic (Bolger et al. 2014) (SLIDINGWINDOW of 3 nts with Q20, MINLEN of $20 \mathrm{nts}$ ). Trimmed data were used in a de novo assembly using CLC Genomics Workbench 10.1.1 (Qiagen) (Default parameters were selected). The de novo assembled contigs were identified using BLAST+ standalone against a local NCBI nucleotide database (BLASTn cut-off e-value of 0.001). The draft genome sequence of the novel viroid-like RNA, PVd-I, was constructed from the overlapping contigs identified in all the symptomatic samples. Its potential circular nature was assessed bioinformatically through read mapping using CLC Genomics Workbench 10.1.1 (Qiagen) (default parameters) on 10 reference genomes. These reference genomes were constructed to represent the complete genome of each of the HTS PVd-I sequence variants with different breakpoints for each of the linear representations of the genome to evaluate if reads span the $5^{\prime}$ and $3^{\prime}$ end of the original reference genome of each HTS variants.

RT-PCR analysis and Sanger sequencing. The $10 \mathrm{HTS}$ assembled draft genomes of PVd-I were used to design primers allowing the amplification of the whole genome by RT-PCR in two different reactions. This was achieved by designing the forward and reverse primers $5^{\prime}$-end to $5^{\prime}$-end in opposite directions on the genome at two different positions in order to generate overlapping amplicons both spanning the complete viroid genome (G1.1 and G1.2) (Table 1). The G1.1 and G1.2 assays were used to test all the material collected in the 2017/2018 and 2018/2019 seasons. All samples were also tested for ACLSV, using the primer set designed by Menzel et al. (2002), and HSVd, using the primer set designed by Astruc et al. (1996). Complementary DNA (cDNA) were synthesized from $1 \mu \mathrm{g}$ of total RNA using $0.15 \mu \mathrm{g}$ of random hexamers (Promega) and Maxima Reverse transcription (Thermo Scientific) in a final volume of $20 \mu \mathrm{l}$ according to manufacturer's instructions. A $2-\mu \mathrm{l}$ aliquot of cDNA was added to $25 \mu \mathrm{l}$ of PCR reaction mixture containing $1 \times$ KAPA Taq buffer A (KAPA Biosystems), $0.2 \mathrm{mM}$ dNTP mix (Thermo Scientific), $0.4 \mu \mathrm{M}$ forward and reverse primers (IDT) (Table 1), and 1.25 U/ $\mu$ KAPA Taq DNA polymerase (KAPA Biosystems). Cycle conditions for the G1.1 and G1.2 assays included an initial denaturation step at $94^{\circ} \mathrm{C}$ for $5 \mathrm{~min}$, followed by 35 cycles of $94^{\circ} \mathrm{C}$ for $10 \mathrm{~s}, 60^{\circ} \mathrm{C}$ for $10 \mathrm{~s}$, and elongation at $72^{\circ} \mathrm{C}$ for $15 \mathrm{~s}$. The cycle conditions for the ACLSV and $\mathrm{HSVd}$ assay included an initial denaturation step at $94^{\circ} \mathrm{C}$ for $5 \mathrm{~min}$, followed by 35 cycles of $94^{\circ} \mathrm{C}$ for $30 \mathrm{~s}, 60^{\circ} \mathrm{C}$ for $30 \mathrm{~s}$ and elongation at $72^{\circ} \mathrm{C}$ for $30 \mathrm{~s}$. Amplicons were visualized on an ethidium bromide-stained 2\% TAE agarose gel (2 M Tris, $1 \mathrm{M}$ glacial acetic acid, and $0.05 \mathrm{M} \mathrm{Na}_{2}$ EDTA, pH 8). All PVd-I-positive amplicons were excised from agarose gels, and DNA was recovered using the Zymoclean Gel DNA Recovery Kit (Zymo Research). Amplicon DNA was sent for bidirectional Sanger sequencing at the Central Analytical Facility at Stellenbosch University.

Detection assay development. All the PVd-I sequence variants generated with Sanger sequencing were used to design primers that were able to detect all variants of PVd-I for a more sensitive assay. An internal control primer set was also designed to target Prunus actin-7 mRNA. The target region of the internal control primer set spans an intron and will result in a 474-bp amplicon if the mRNA target is amplified and a 601-bp amplicon if the DNA target is amplified. A multiplex PCR assay (G2actin) was developed for the detection of PVd-I. The 25- $\mu$ l reaction mixture contained $2 \mu \mathrm{l}$ of cDNA, 1× KAPA Taq buffer A (KAPA Biosystems), $0.2 \mathrm{mM}$ dNTP mix (Thermo Scientific), $0.6 \mu \mathrm{M}$ PVd-I_22F and PVd-I_21R primers (IDT) (Table 1), $0.2 \mu \mathrm{M}$ Plum_ Actin7_1137F and Plum_Actin7_1610R primers (IDT) (Table 1),

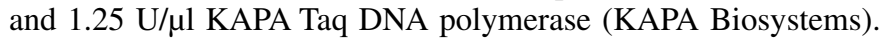
Cycle conditions included an initial denaturation step at $94^{\circ} \mathrm{C}$ for $5 \mathrm{~min}$, followed by 35 cycles of $94^{\circ} \mathrm{C}$ for $10 \mathrm{~s}, 60^{\circ} \mathrm{C}$ for $10 \mathrm{~s}$, and elongation at $72^{\circ} \mathrm{C}$ for $15 \mathrm{~s}$.

TABLE 1. Primer set properties for the plum viroid I (PVd-I) detection assays

\begin{tabular}{|c|c|c|c|c|c|c|}
\hline Primer name & Sequence $\left(5^{\prime}-3^{\prime}\right)$ & $\begin{array}{l}\text { Amplicon } \\
\text { size }\end{array}$ & Target & $\begin{array}{l}\text { Assay } \\
\text { name }\end{array}$ & $\begin{array}{c}\text { Primer } \\
\text { concentration } \\
(\mu \mathrm{M})\end{array}$ & $\begin{array}{l}\text { Annealing } \\
\text { temperature } \\
\left({ }^{\circ} \mathrm{C}\right)\end{array}$ \\
\hline PVd-I_44F & AGAGGTTCTCCGTCTTTACTC & 316 & Plum viroid I (PVd-I) & G1.1 & 0.4 & 60 \\
\hline PVd-I_43R & CGAAAGAGACTGACTCCG & & Plum viroid I (PVd-I) & G1.1 & 0.4 & 60 \\
\hline PVd-I_206F & ACACCAATCGTGTTTTCCCC & 316 & Plum viroid I (PVd-I) & G1.2 & 0.4 & 60 \\
\hline PVd-I_205R & TCTCCACTGGTGAACAACCTG & & Plum viroid I (PVd-I) & G1.2 & 0.4 & 60 \\
\hline ACLSV_s ${ }^{\mathrm{a}}$ & TTCATGGAAAGACAGGGGCAA & 677 & $\begin{array}{l}\text { Apple chlorotic leaf spot } \\
\text { virus (ACLSV) }\end{array}$ & ACLSV & 0.4 & 60 \\
\hline ACLSV_as ${ }^{\mathrm{a}}$ & AAGTCTACAGGCTATTTATTATAAGTCTAA & & $\begin{array}{l}\text { Apple chlorotic leaf spot } \\
\text { virus (ACLSV) }\end{array}$ & ACLSV & 0.4 & 60 \\
\hline VP19 & GCCCCGGGGCTCCTTTCTCAGGTAAG & 297 & Hop stunt viroid (HSVd) & HSVd & 0.4 & 60 \\
\hline VP20 & CGCCCGGGGCAACTCTTCTCAGAATC & & Hop stunt viroid (HSVd) & HSVd & 0.4 & 60 \\
\hline PVd-I_22F & TCTCCACTGGTGAACAACC & 316 & Plum viroid I (PVd-I) & G2actin & 0.6 & 60 \\
\hline PVd-I_21R & ACACCAATCGTGTTTTCCC & & Plum viroid I (PVd-I) & G2actin & 0.6 & 60 \\
\hline Plum_Actin7_1137F & CTCCAAGCAGCATGAAGATTA & & Prunus actin 7 mRNA & G2actin & 0.2 & 60 \\
\hline Plum_Actin7_1610R & GAAGCATCCCAATCACTCTC & 474 & Prunus actin 7 mRNA & G2actin & 0.2 & 60 \\
\hline
\end{tabular}

a Menzel et al. (2002). 
Genome analysis. Multiple sequence alignments were performed with Mega X (Kumar et al. 2016, 2018) using a representative sequence of PVd-I (AK8, GenBank accession number MN734701) and all the RefSeq viroid sequences are available in GenBank. Sequence identity was determined with CLC main workbench 7.6.4 (Qiagen). A phylogenetic tree was constructed with 1,000 bootstrap replicates using the maximum likelihood method and Jukes-Cantor model in Mega X (Felsenstein 1985; Jukes and Cantor 1969; Kumar et al. 2016, 2018).

The sequence demarcation tool (SDT) (Muhire et al. 2014) was used to align every unique pair of sequences using MUSCLE (Edgar 2004). Sequences were ordered according to their likely degrees of evolutionary relatedness, using a rooted neighbor-joining phylogenetic tree, to generate a frequency distribution of pairwiseidentities. CLC main workbench 7.6.4 (Qiagen) was used to predict the secondary structure of PVd-I sequence variant AK8.

Seed transmission. To examine transmission of PVd-I through seed, fruit from five trees (cultivars African Delight and Ruby Star)
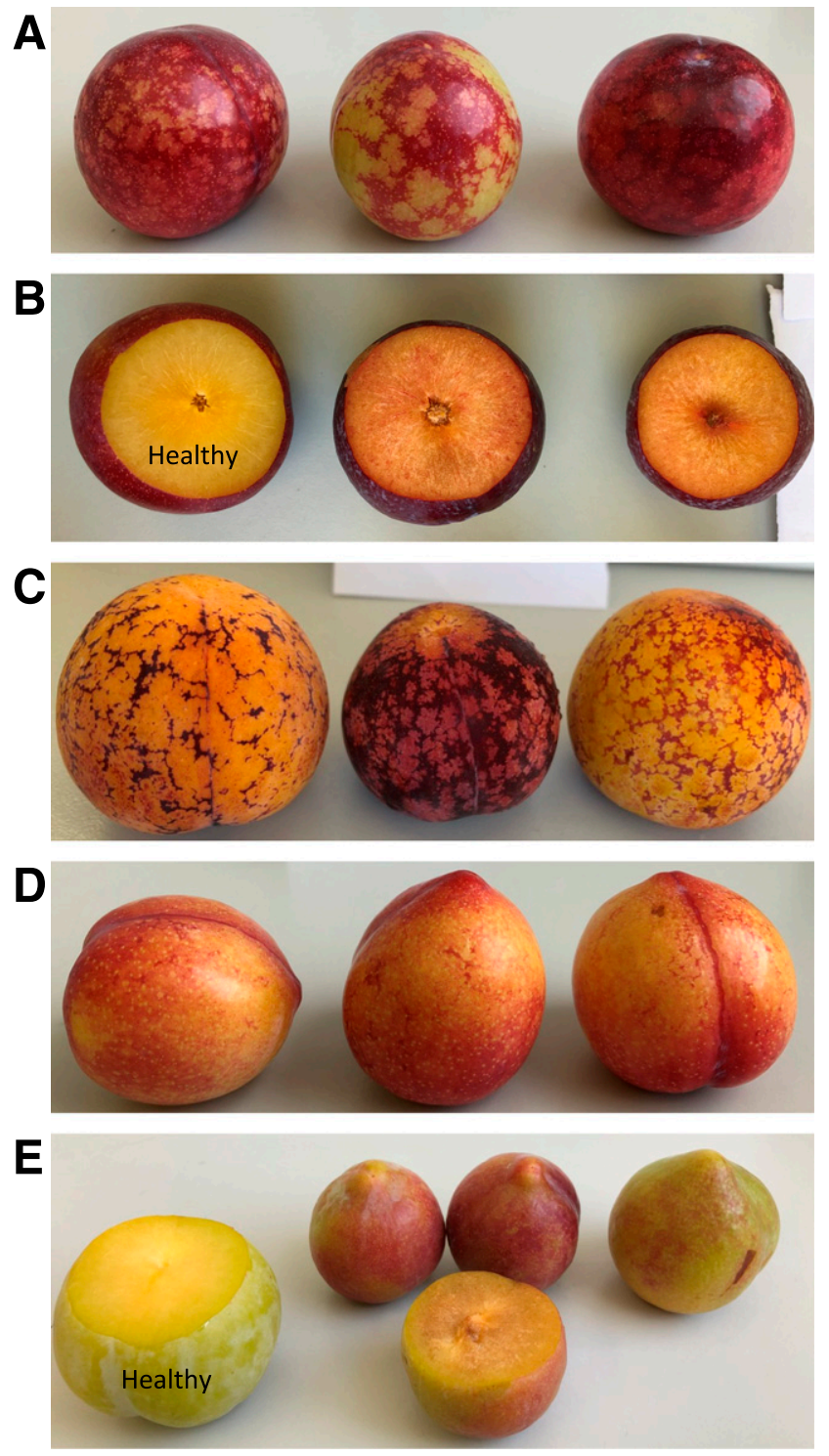

Fig. 1. Symptom expression observed in different plum cultivars. A, Marbling symptoms observed in Prunus salicina 'African Delight'. B, Corky flesh symptoms observed in Prunus salicina 'Ruby Star' compared with a healthy fruit (left). C, Marbling symptoms observed in Prunus salicina 'Pioneer'. D, Marbling symptoms observed in Prunus salicina 'Laetitia'. E, Corky flesh symptoms with red blush observed in Prunus salicina 'SunBreeze' compared with healthy fruit (left). were collected in the week before harvest. The plum pits were extracted from the fruits, and the seeds were removed by cracking open the pit. All seeds were treated with Promalin and sowed in potting soil. The optimal sample size was determined using the power calculation for $\chi^{2}$ tests in the $\mathrm{R}$ statistical computing environment using the pwr package (CRAN). At 5 months, the seedlings were sampled, and RNA was extracted and tested with the G1.1, G1.2, and G2actin assay.

Graft transmission. To verify that the viroid sequence identified in symptomatic samples was associated with a grafttransmissible agent, transmissibility was demonstrated by grafting buds from an infected Ruby Star tree (accession AK8) onto 1-yearold trees of 12 different cultivars (African Delight [10 trees], Ruby Sun [10 trees], Laetitia [8 trees], Ruby Star [10 trees], Southern Belle [10 trees], Suplumsix [10 trees], Black Splendor [10 trees], Sunkiss [10 trees], Fortune [10 trees], Songold [10 trees], Pioneer [4 trees], and Harry Pickstone [10 trees]). The same number of healthy control trees per cultivar were included in the experiment. All trees were tested prior to inoculation to verify the absence of detectable levels of PVd-I and ACLSV. Viroid transmission was verified by RT-PCR 9 months after inoculation with the G2actin detection assay. In cases where the graft-inoculated recipient plants tested negative and the grafted Ruby Star donor bud from AK8 grew out on the recipient plant, the Ruby Star leaf material was also tested.

\section{RESULTS}

Description of disease symptoms. Symptom expression associated with the presence of PVd-I in plums was only visible on the fruit after fruit coloration. No other visible symptoms were observed on trees. Symptoms included skin marbling (Fig. 1A); corky flesh (Fig. 1B); hard, small, and irregular fruit; and fruit with an uneven surface. The symptom expression also ranged in severity between cultivars, with Pioneer (Fig. 1C) and African Delight (Fig. 1A) showing severe marbling and Laetitia (Fig. 1D) showing a mild form of marbling. Ruby Star was the only cultivar evaluated with no marbling, but severe corky flesh and uneven surfaced fruit (Fig. 1B). Sunbreeze was the only yellow-flesh cultivar evaluated, and fruit from infected trees were small, irregular, and had severe corky flesh (Fig. 1E). An uncharacteristic red blush was also visible.

HTS data analysis. An average of 19 million read pairs per sample were received after HTS. The total number of trimmed sequence read pairs ranged from 12 to 19 million per sample, which resulted in the assembly of an average of 44,000 contigs after de novo assembly (Table 2). These contigs were annotated by BLASTn analyses against the nucleotide database of NCBI. No known fruit tree viruses were identified in any of the samples. However, viroidlike contigs were identified in all the samples that displayed either marbling on the fruit skin or corky flesh within the fruit. These viroid-like contigs had the highest sequence identity to apple dimple fruit viroid (ADFVd) or citrus dwarfing viroid (CDVd), which are members of the genus Apscaviroid, family Pospiviroidae (Table 3).

The read mapping to the individual rearranged PVd-I contigs showed the presence of reads that spanned the original $5^{\prime}$ and $3^{\prime}$ end of the contigs, indicating the likely circular nature of these viroid sequences. HSVd sequences were identified in only 5 of the 10 symptomatic samples (Table 2). False positive results are a possibility in HTS (Dickins et al. 2014; Maree et al. 2018), and therefore HSVd targets with a read count below 50 were validated with RT-PCR. No HSVd was detected with RT-PCR in sample AK14, where only six reads where found by HTS.

PVd-I association with symptoms. In the 2017/2018 season, 20 healthy samples and 30 symptomatic samples were collected. All healthy samples tested negative and all symptomatic samples tested positive for PVd-I. In the 2018/2019 season, 95 of the 97 healthy samples tested negative and 91 of the 94 symptomatic samples tested positive for PVd-I. All samples tested negative for ACLSV. 
No association between the presence of HSVd and symptom expression could be observed. Collectively, only $36 \%$ of the symptomatic trees and $13 \%$ of the healthy trees tested positive for HSVd.

Genome characterization. The primary structure of PVd-I was determined by direct sequencing of the overlapping RT-PCR amplicons obtained with the G1.1 and G1.2 assays (Table 1). Eighty-six complete genome sequences of PVd-I were generated using Sanger sequencing. The sequence variants were on average $99.1 \%$ identical with the most diverse variant being 96.8 to $98.7 \%$ identical compared with the other sequence variants. Sequence variant AK8 was selected as the representative sequence of PVd-I as it was identical to the majority of the sequence variants and represents the consensus sequence. The tree AK8 was also subjected to HTS and buds from this tree were used for the graft transmission experiment. The genome of sequence variant AK8 consists of $317 \mathrm{~ns}$ with a $\mathrm{C}+\mathrm{G}$ content of $56.8 \%$. The secondary structure of minimum free energy predicted a rod containing a central conserved region (CCR) (Fig. 2), which is the main criterion to classify a new viroid as a member of the family Pospiviroidae. Furthermore, the type of CCR and the presence of a terminal conserved region (TCR) should be taken into consideration to likely classify PVd-I as a member of the genus Apscaviroid.

Using BLASTn, PVd-I contigs showed the highest nucleotide sequence identity to apple dimple fruit viroid and citrus dwarfing viroid (Table 3). However, identities were less than $77 \%$. The HTS and Sanger sequenced nucleotide sequences of the $86 \mathrm{PVd}-\mathrm{I}$ sequence variants are deposited in the NCBI GenBank (GenBank accessions numbers MN734701 to MN734786).

Phylogenetic analysis. Although autonomous replication of PVd-I has not been addressed in this study, the molecular features of viroid-like RNAs reported above strongly support that it is a novel viroid. Phylogenetic analyses were performed, including a representative sequence variant of PVd-I (AK8, GenBank accession number MN734701), and all reference sequences (RefSeq) are available in GenBank for current members of the families Pospiviroidae and the RefSeq of peach latent mosaic viroid (family Avsunviroidae) used as an outgroup. A phylogenetic tree based on the maximum likelihood method and Jukes-Cantor model, in which PVd-I groups with the current members of the genus Apscaviroid within the family Pospiviridae, is shown in Figure 3. The SDT analysis based on pairwise comparisons also shows that none of the viroid sequences available in GenBank are more than $80 \%$ similar across the complete genome (Fig. 4).
Seed transmission. Approximately 400 seeds were treated with Promilin, of which 206 germinated. At 5 months, the seedlings were sampled irrespective of size and 203 yielded total RNA of sufficient quality to be screened with all three detection assays (G1.1/G1.2, and G2actin). All seedlings tested negative. The number of samples that needed to be assayed for a statistically significant answer was calculated to be between 87 and 117, assuming an 80 to $90 \%$ power to correctly reject the null hypothesis when it is false. Degrees of freedom was set to one, significance level to 0.05 , and effect size of 0.3 was selected for the RT-PCR assays. Assuming the same parameters, the 203 tested samples have a test power of $98 \%$. When the significance level is lowered to 0.01 , the test power is $95 \%$.

Graft-transmissibility. Prior to inoculation of the trees using the infected Ruby Star buds, seven trees tested positive for PVd-I using the G1.1 and G1.2 assays. These trees were moved to the grafted group of each cultivar and also inoculated with the infected Ruby Star buds from accession AK8. At 9 months postinoculation, the 116 plants that were not inoculated tested negative for PVd-I using the G2actin assay. In all, 70 of the 120 plants that were inoculated with the infected buds tested positive for PVd-I. Thirteen of the inoculated buds on trees that tested negative grew out and could also be tested. All of the Ruby Star plant material tested positive for PVd-I even though the recipient plant tested negative at 9 months postinoculation. At the end of the summer season of $2019 / 2020$, marbling symptoms were observed on fruits from

TABLE 3. The nucleotide sequence identity and query coverage for each of the high-throughput sequencing plum viroid I (PVd-I) sequence variants compared with the closest match available in NCBI GenBank

\begin{tabular}{lcc}
\hline & \multicolumn{2}{c}{$\begin{array}{c}\text { BLASTn PVd-I contig sequence identity and query } \\
\text { coverage }\end{array}$} \\
\cline { 2 - 3 } Sample & Apple dimple fruit viroid & Citrus dwarfing viroid \\
\hline AK2 & $74.51(95)^{\mathrm{a}}$ & $72.96(94)$ \\
AK3 & $76.05(96)$ & $73.23(94)$ \\
AK6 & & $73.63(95)$ \\
AK7 & $74.43(96)$ & $72.90(94)$ \\
AK8 & & $73.63(95)$ \\
AK10 & & $73.40(95)$ \\
AK13 & & $73.40(95)$ \\
AK14 & $74.51(95)$ & $72.96(94)$ \\
AK17 & & $73.63(95)$ \\
AK25 & $74.51(95)$ & $72.96(94)$ \\
\hline
\end{tabular}

a Percent identity (query coverage).

TABLE 2. Descriptive statistics for each high-throughput sequencing library ${ }^{a}$

\begin{tabular}{|c|c|c|c|c|c|c|c|c|}
\hline \multirow[b]{2}{*}{ Sample } & \multirow[b]{2}{*}{$\begin{array}{c}\text { Fruit } \\
\text { symptom }\end{array}$} & \multirow{2}{*}{$\begin{array}{l}\text { Number of read } \\
\text { pairs after quality } \\
\text { trimming }\end{array}$} & \multirow{2}{*}{$\begin{array}{c}\text { Number of } \\
\text { de novo assembled } \\
\text { contigs }\end{array}$} & \multicolumn{5}{|c|}{ BLASTn results } \\
\hline & & & & $\begin{array}{c}\text { Virus } \\
\text { sequences }\end{array}$ & $\begin{array}{c}\text { Viroid sequences } \\
\text { detected }\end{array}$ & $\begin{array}{c}\text { Consensus length } \\
\text { (nt) }\end{array}$ & $\begin{array}{c}\text { Total read } \\
\text { count }\end{array}$ & $\begin{array}{l}\text { Average } \\
\text { coverage }\end{array}$ \\
\hline $\mathrm{AK} 2$ & Marbling & $17,257,574$ & 41,032 & None & PVd-I/HSVd & $316 / 316$ & $3,440 / 9$ & $1,000.82 / 2.87$ \\
\hline $\mathrm{AK} 3$ & Marbling & $15,159,682$ & 45,507 & None & PVd-I/HSVd & $296 / 324$ & $1,717 / 2,252$ & $474.28 / 687.22$ \\
\hline AK6 & Marbling & $16,811,672$ & 41,282 & None & PVd-I/HSVd & $316 / 473$ & $1,539 / 44$ & 450.218 .86 \\
\hline AK7 & Marbling & $18,752,472$ & 37,225 & None & PVd-I/HSVd & $264 / 296$ & $2,125 / 2,167$ & 713.88/687.04 \\
\hline AK10 & Marbling & $13,629,019$ & 39,457 & None & PVd-I & 317 & 5,593 & $1,585.43$ \\
\hline AK13 & Marbling & $15,274,467$ & 40,528 & None & PVd-I & 317 & 4,796 & $1,356.71$ \\
\hline AK17 & Marbling & $16,738,585$ & 40,374 & None & PVd-I & 316 & 4,038 & $1,194.78$ \\
\hline AK8 & Corky flesh & $19,104,002$ & 52,039 & None & PVd-I & 295 & 638 & 204 \\
\hline AK14 & Corky flesh & $17,007,762$ & 42,687 & None & PVd-I/HSVd & $316 / 309$ & $5,453 / 6^{*}$ & $1,576.76 / 1.96$ \\
\hline AK25 & Corky flesh & $16,778,647$ & 44,574 & None & PVd-I & 316 & 1,3147 & $3,773.25$ \\
\hline $\mathrm{AK} 4$ & None & $15,027,564$ & 42,791 & None & None & & & \\
\hline AK5 & None & $17,878,518$ & 41,344 & None & None & & & \\
\hline AK 9 & None & $14,950,472$ & 40,607 & None & None & & & \\
\hline AK21 & None & $16,184,588$ & 43,267 & None & None & & & \\
\hline AK23 & None & $14,220,392$ & 42,177 & None & None & & & \\
\hline
\end{tabular}

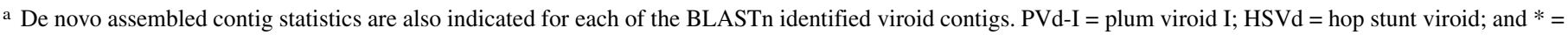
not detected with RT-PCR. 
PVd-I-infected trees of cultivars Pioneer and Laetitia. Not all cultivars yielded fruit in the first season.

\section{DISCUSSION}

This study is the first report of a potential novel viroid associated with plum marbling disease. HTS was utilized to identify all the potential viruses/viroids associated with the marbling and corky flesh symptoms. Only PVd-I was identified to be consistently associated with the disease symptoms. PVd-I is between 72 and
$76 \%$ similar to any other viroid sequence available in the NCBI GenBank database, with closest identity to ADFVd and CDVd. Although the infectivity of PVd-I has been confirmed by grafttransmission experiments in this study, its autonomous replication, and the existence of biological features divergent from the most closely related apscaviroids, other relevant criteria for conclusive classification of viroids (Di Serio et al. 2017) remain to be further investigated. However, so far no other viroid has been associated with marbling or corky flesh, thus suggesting that PVd-I has a different biological behavior with respect to HSVd and PLMVd, the

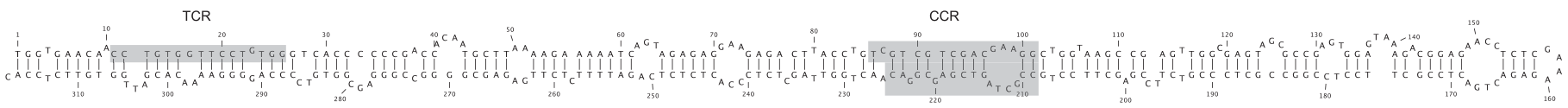

Fig. 2. Proposed secondary structure of minimum free energy of plum viroid I (PVd-I) (sequence variant AK8) predicted with CLC main workbench 7.6.4 (Qiagen). Nucleotides forming the terminal conserved region (TCR) at positions 11 to 26 and the central conserved region (CCR) at positions 86 to 101 and 209 to 225 are highlighted.

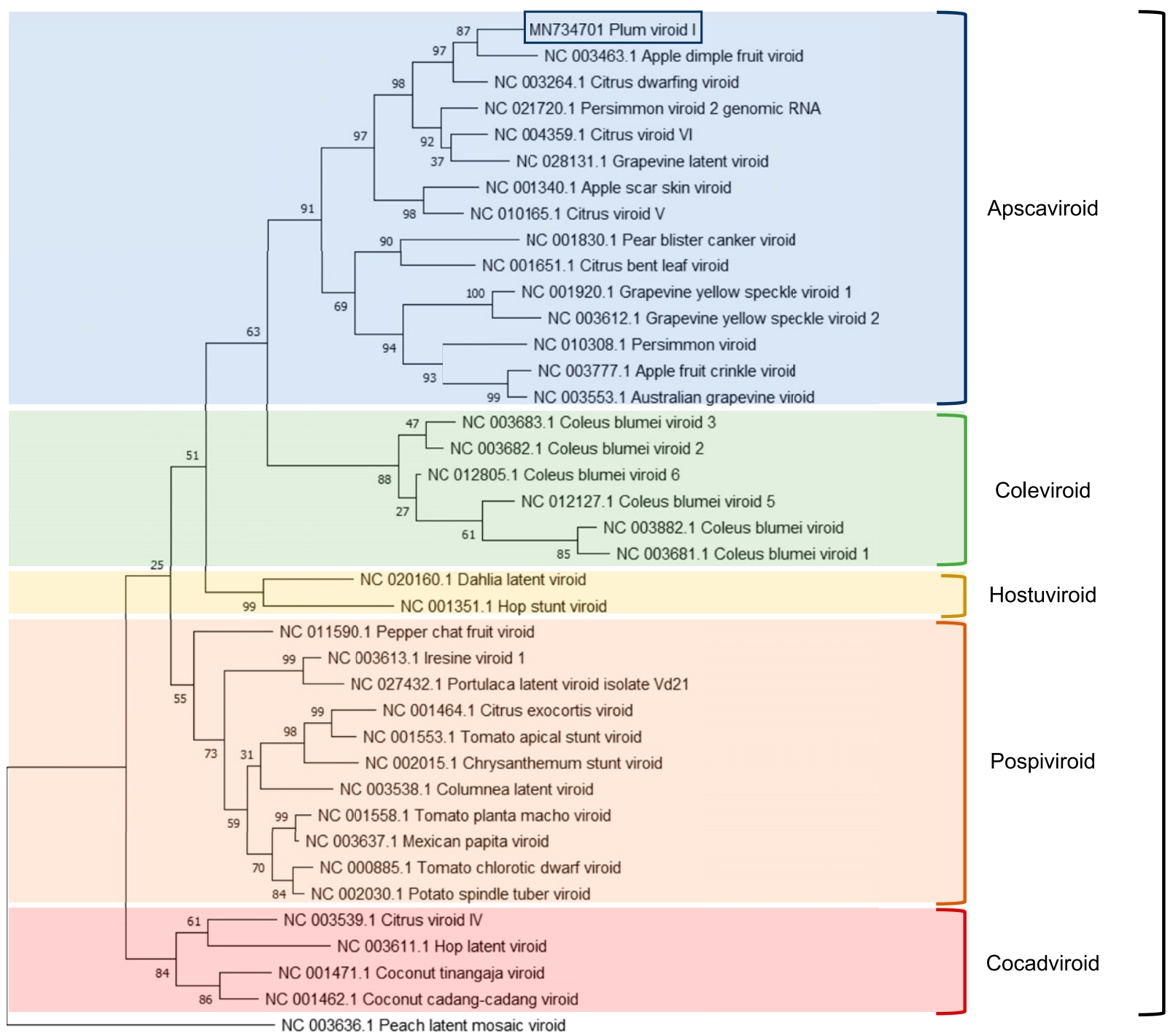

Pospiviroidae

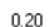

Fig. 3. Evolutionary relationships of plum viroid I (PVd-I) (sequence variant AK8, MN734701) and all current Refseq viroid sequences available in GenBank for the family Pospiviroidae. The phylogenetic tree was constructed with 1,000 bootstrap replicates using the maximum likelihood method and Jukes-Cantor model in Mega X (Felsenstein 1985; Jukes and Cantor 1969; Kumar et al. 2016, 2018). The percentage of replicate trees in which the associated taxa clustered together in the bootstrap test ( 1,000 replicates) are shown next to the branches. The tree is drawn to scale, with branch lengths measured in the number of substitutions per site. Peach latent mosaic viroid (PLMVd) (family Avsunviroidae) was included as an outgroup to compare the different genera of the family Pospiviroidae. 
only viroids known to infect stone fruit trees so far. Phylogenetic analysis supports the classification of PVd-I as a member of the genus Apscaviroid. The SDT analysis based on pairwise comparisons is also consistent with considering PVd-I as new viroid species.

Marbling disease has been observed by the South African plum industry for more than 20 years on various plum cultivars. No aetiological agent could consistently be associated with any of the reported symptoms, and the situation was further complicated by the symptom overlap with ACLSV. Since not all symptomatic plum trees tested positive for ACLSV, an unknown aetiological agent was suspected.

HTS provides the ideal methodology to determine the complete virus and viroid infection status of a plant. It does not rely on the availability of genomic sequence information like RT-PCR and is only limited by the completeness of the reference database(s) against which the sequences are compared.

Analyses of HTS data of 15 plants yielded virome profiles that revealed that the only consistently associated entity with symptomatic trees was PVd-I.
HSVd has been reported to be associated with dapple fruit disease in plums in Japan in 1968 (Sano 2011; Sano et al. 1989). The disease was colloquially referred to as "Kirin-ka," meaning a fruit with giraffe-like patches. Subsequently, it was also reported in Italy (Ragozzino et al. 2002). The skin symptom description for dapple fruit disease overlaps with marbling disease and could potentially be difficult to differentiate in the field. However, in the present study no association between symptom expression and the presence of HSVd was detected.

To further evaluate the association of the presence of PVd-I with disease symptoms, surveys were conducted in 2017/2018 and 2018/ 2019. In the first season, a limited survey showed a $100 \%$ association of PVd-I with marbling disease. In the 2018/2019 season, the survey was expanded and PVd-I was detected in $97 \%$ of the symptomatic samples. Two of the healthy samples did however test positive for PVd-I, but this can be ascribed to a sampling error since cultivar Ruby Crunch is a black plum on which marbling symptoms are difficult to observe at harvest when the sampling was done.
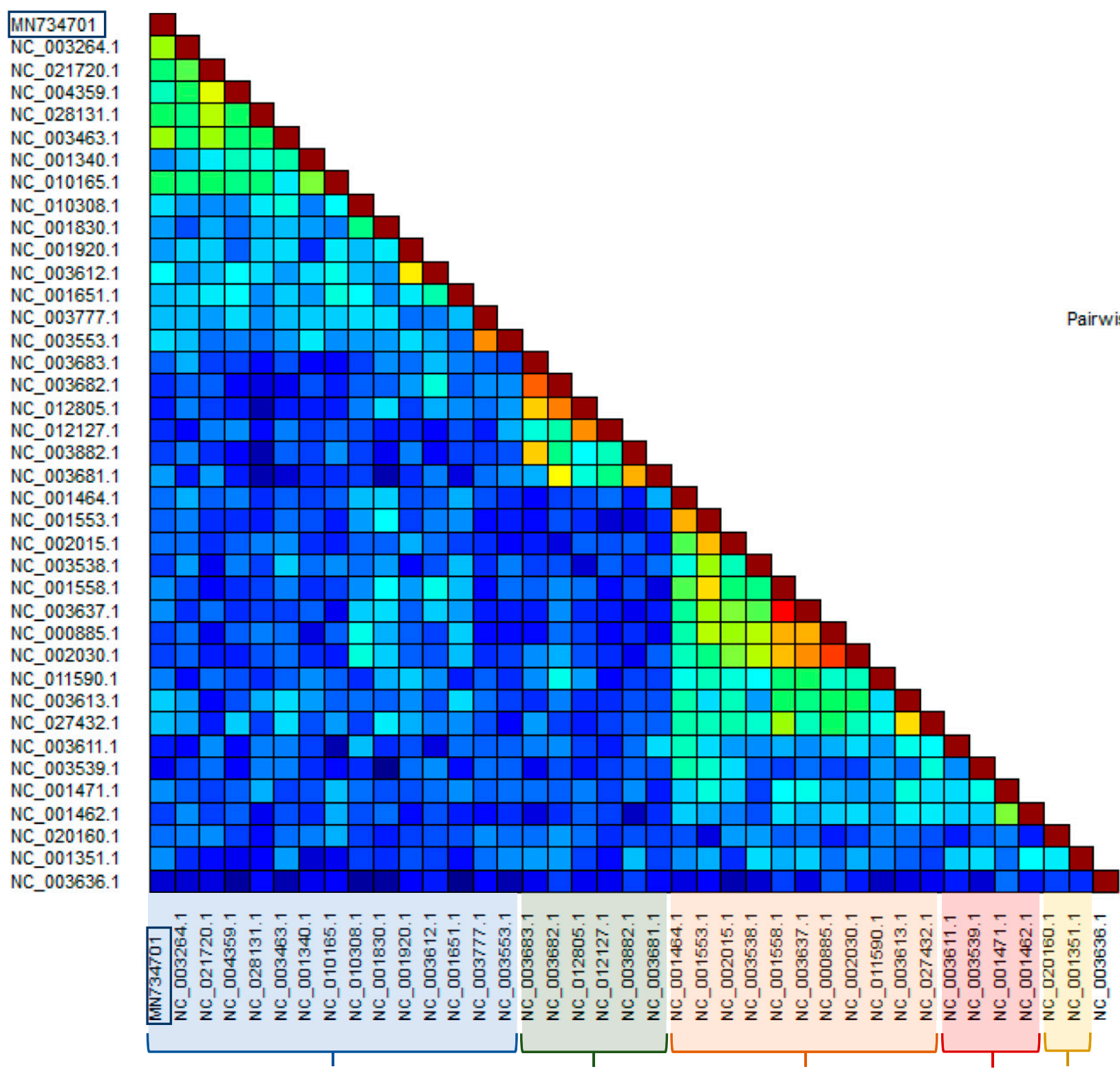

Apscaviroid

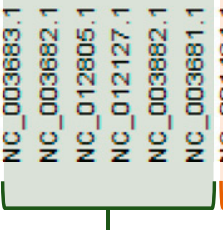

Coleviroid

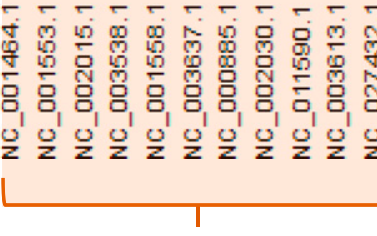

Pospiviroid
Pairwise identity (\%)

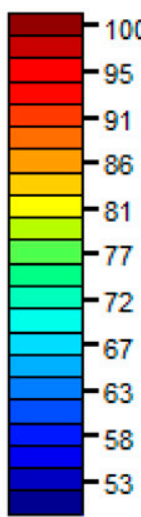

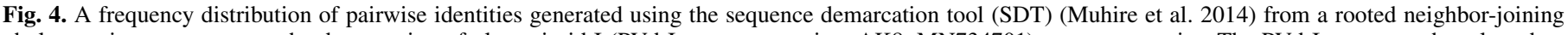

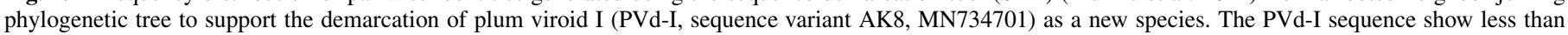

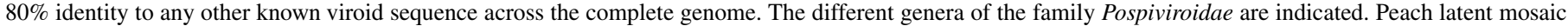
viroid (PLMVd, NC_003636) (family Avsunviroidae) was included as an outgroup. 
No PVd-I could be detected in any of the 203 seedlings that were raised from PVd-I-infected plums. Therefore, to date, an infection rate of $0 \%$ is suggested, assuming that the nonemergence of the more than 190 seeds was not correlated to viroid infection. Whether PVd-I is seedborne but not transmitted was not tested. PVd-I was successfully transmitted to $58 \%$ of the trees grafted, demonstrating that PVd-I is graft transmissible to multiple plum cultivars. This agrees with previous observations with other pospiviroids infecting stone fruit (Giunchedi et al. 2011; Sano 2011). PVd-I-associated symptoms were also observed in the first season after infection occurred.

The $58 \%$ graft transmission efficiency of PVd-I and the observation that some cultivars had a higher graft transmission rate than others can potentially indicate susceptibility variation between cultivars to PVd-I. However, more data are required to rule out tree growth stage, bud death due to inefficient grafting, and PVd-I concentration in donor buds that could influence graft transmission efficiency.

The main feature of viroids is their autonomous replication and therefore, graft-transmissibility is not sufficient to illustrate that a circular (viroid-like) RNA is a viroid. Future experiments will be directed toward proving the autonomous replication of the infectious agent.

The origin of PVd-I infection in plums is unclear. Anecdotal evidence from plum producers suggests that PVd-I spreads very slowly in the field if at all. This suggests that the probability of mechanical transmission through pruning shears may also be low. Good sanitary practices from producers also showed that no secondary spread occurs if infected trees get pruned separately from healthy trees. This slow secondary spread implies that if there was an insect vector, the vector might not be present.

The application of HTS proved to be very useful to solve a two decade old mystery and provide further support for the need to adopt HTS as an integral component of pathogen detection protocols in plant quarantine and certification schemes.

Future research regarding PVd-I will need to be directed toward the investigation into possible alternative and asymptomatic hosts. The strong association to date between the presence of PVd-I and symptomatic fruit makes symptomatic fruit the easiest and most cost effective way to screen a high number of plants. The complete species and cultivar host range still need to be determined and symptom expression compared. Mode of transmission will also need to be investigated further to assess the rate of mechanical spread as well as the existence of a potential insect vector. Reports by producers also provided anecdotal evidence of a possible climatic stress trigger that needs to be investigated.

This study is the first to report the presence of a potential third viroid species that can infect stone fruit.

\section{ACKNOWLEDGMENTS}

We thank the South African nurseries for plant material, and the plum producers for allowing us to collect samples and the valuable conversations to understand the impact and disease status from a producers' perspective.

\section{LITERATURE CITED}

Astruc, N., Marcos, J. F., Macquaire, G., Candresse, T., and Pallás, V. 1996. Studies on the diagnosis of hop stunt viroid in fruit trees: Identification of new hosts and application of a nucleic acid extraction procedure based on non-organic solvents. Eur. J. Plant Pathol. 102:837-846.

Bolger, A. M., Lohse, M., and Usadel, B. 2014. Trimmomatic: A flexible trimmer for Illumina sequence data. Bioinformatics 30:2114-2120.

Di Serio, F., Flores, R., Verhoeven, J. Th. J., Li, S.-F., Pallás, V., Randles, J. W., Sano, T., Vidalakis, G., and Owens, R. A. 2014. Current status of viroid taxonomy. Arch. Virol. 159:3467-3478.

Di Serio, F., Li, S.-F., Pallás, V., Owens, R. A., Randles, J. W., Sano, T., Verhoeven, J. T. J., Vidalakis, G., and Flores, R. 2017. Viroid taxonomy. Pages 135-146 in: Viroids and Satellites. A. Hadidi, R. Flores, J. W. Randles, and P. Palukaitis, eds. Academic Press, Boston, MA.
Dickins, B., Rebolledo-Jaramillo, B., Su, M. S.-W., Paul, I. M., Blankenberg, D., Stoler, N., Makova, K. D., and Nekrutenko, A. 2014. Controlling for contamination in re-sequencing studies with a reproducible web-based phylogenetic approach. Biotechniques 56:134-141.

Diener, T. O. 1999. Viroids and the nature of viroid diseases. Pages 203-220 in: 100 Years of Virology. C. H. Calisher and M. C. Horzinek, eds. Springer, Vienna.

Edgar, R. C. 2004. MUSCLE: Multiple sequence alignment with high accuracy and high throughput. Nucleic Acids Res. 32:1792-1797.

Felsenstein, J. 1985. Confidence limits on phylogenies: An approach using the bootstrap. Evolution 39:783-791.

Flores, R., Di Serio, F., and Hernández, C. 1997. Viroids: The noncoding genomes. Semin. Virol. 8:65-73.

Giunchedi, L., Kyriakopoulou, P. E., Barba, M., and Hadidi, A. 2011. Chapter 41: Peach latent mosaic viroid in naturally infected temperate fruit trees. Pages 225-227 in: Virus and Virus-Like Diseases of Pome and Stone Fruits. American Phytopathological Society, St. Paul, MN.

Hortgro. 2018. Key Deciduous Fruit Statistics. https://www.hortgro.co.za/wpcontent/uploads/docs/2019/06/stone-fruit-2018.pdf

Jakse, J., Radisek, S., Pokorn, T., Matousek, J., and Javornik, B. 2015. Deepsequencing revealed Citrus bark cracking viroid (CBCVd) as a highly aggressive pathogen on hop. Plant Pathol. 64:831-842.

Jukes, T. H., and Cantor, C. R. 1969. Evolution of protein molecules. Pages 21-132 in: Mammalian Protein Metabolism. Elsevier.

Kumar, S., Stecher, G., Li, M., Knyaz, C., and Tamura, K. 2018. MEGA X: Molecular evolutionary genetics analysis across computing platforms. Mol. Biol. Evol. 35:1547-1549.

Kumar, S., Stecher, G., and Tamura, K. 2016. MEGA7: Molecular evolutionary genetics analysis version 7.0 for bigger datasets. Mol. Biol. Evol. 33:1870-1874.

Maree, H. J., Fox, A., Al Rwahnih, M., Boonham, N., and Candresse, T. 2018. Application of HTS for routine plant virus diagnostics: State of the art and challenges. Front. Plant Sci. 9:1082

Massart, S., Olmos, A., Jijakli, H., and Candresse, T. 2014. Current impact and future directions of high throughput sequencing in plant virus diagnostics. Virus Res. 188:90-96.

Menzel, W., Jelkmann, W., and Maiss, E. 2002. Detection of four apple viruses by multiplex RT-PCR assays with coamplification of plant mRNA as internal control. J. Virol. Methods 99:81-92.

Muhire, B. M., Varsani, A., and Martin, D. P. 2014. SDT: A virus classification tool based on pairwise sequence alignment and identity calculation. PLoS One 9:e108277.

Myrta, A., Matic, S., Malinowski, T., Pasquini, G., and Candresse, T. 2011. Chapter 17: Apple chlorotic leaf spot virus in stone fruits. Pages 85-90 in: Virus and Virus-Like Diseases of Pome and Stone Fruits. American Phytopathological Society, St. Paul, MN.

Navarro, B., Minutolo, M., Stradis, A. D., Palmisano, F., Alioto, D., and Serio, F. D. 2017. The first phlebo-like virus infecting plants: A case study on the adaptation of negative-stranded RNA viruses to new hosts. Mol. Plant Pathol. 19:1075-1089.

Navarro, B., Zicca, S., Minutolo, M., Saponari, M., Alioto, D., and Di Serio, F. 2018. A negative-stranded RNA virus infecting citrus trees: The second member of a new genus within the order Bunyavirales. Front. Microbiol. 9:2340.

Ragozzino, E., Faggioli, F., Amatruda, G., and Barba, M. 2002. Occurrence of dapple fruit of plum in Italy. Phytopathol. Mediterr. 41:72-75.

Rott, M., Xiang, Y., Boyes, I., Belton, M., Saeed, H., Kesanakurti, P., Hayes, S., Lawrence, T., Birch, C., Bhagwat, B., and Rast, H. 2017. Application of next generation sequencing for diagnostic testing of tree fruit viruses and viroids. Plant Dis. 101:1489-1499.

Rott, M. E., Kesanakurti, P., Berwarth, C., Rast, H., Boyes, I., Phelan, J., and Jelkmann, W. 2018. Discovery of negative-sense RNA viruses in trees infected with apple rubbery wood disease by next-generation sequencing. Plant Dis. 102:1254-1263.

Ruiz-García, A. B., Bester, R., Olmos, A., and Maree, H. J. 2019. Bioinformatic Tools and Genome Analysis of citrus tristeza virus. Pages 163-178 in: Citrus Tristeza Virus: Methods and Protocols. A. F. Catara, M. Bar-Joseph, and G. Licciardello, eds. Springer, New York.

Sano, T. 2011. Chapter 42: Hop stunt viroid. Pages 229-232 in: Virus and Virus-Like Diseases of Pome and Stone Fruits. American Phytopathological Society, St. Paul, MN.

Sano, T., Hataya, T., Terai, Y., and Shikata, E. 1989. Hop stunt viroid strains from dapple fruit disease of plum and peach in Japan. J. Gen. Virol. 70:1311-1319.

Sõmera, M., Kvarnheden, A., Desbiez, C., Blystad, D.-R., Sooväli, P., Kundu, J. K., Gantsovsky, M., Nygren, J., Lecoq, H., Verdin, E., Spetz, C., Tamisier, L., Truve, E., and Massart, S. 2019. Sixty years after the first description: Genome sequence and biological characterization of European wheat striate mosaic virus infecting cereal crops. Phytopathology 110:68-79.

Villamor, D. E. V., Mekuria, T. A., Pillai, S. S., and Eastwell, K. C. 2016. High-throughput sequencing identifies novel viruses in nectarine: Insights to the etiology of stem-pitting disease. Phytopathology 106:519-527. 